\title{
Reassessing Innovative Work Behaviors during COVID-19 Pandemic: The Impacts of Workplace Spirituality and Psychological Safety Perception
}

\author{
Seçil TAŞTAN \\ Marmara Üniversitesi İşletme Fakültesi İşletme (İng) Bölümü \\ seciltastan@marmara.edu.tr \\ ORCID: https://orcid.org/0000-0003-3243-3989 \\ Serin İşi̇AÇIK \\ FMV Ișık Üniversitesi, Fen-Edebiyat Fakültesi, Psikoloji Bölümü \\ serin.isiacik@isikun.edu.tr \\ ORCID: https://orcid.org/0000-0002-6861-2287
}

\begin{tabular}{|c|c|}
\hline Araştırma Makalesi & DOI: $10.31592 /$ aeusbed.736610 \\
\hline Geliş Tarihi: 13.05 .2021 & Revize Tarihi: 19.05 .2021 \\
\hline
\end{tabular}

ABSTRACT

Recent literature has shown the contributions of positivity in organizations, but less is known about the impact of spirituality and safety feelings as an extension of positive psychology on individuals' innovative work behaviors. Considering the COVID-19 pandemic outbreak, it is suggested that the conditions encouraging employees' perceptions and attitudes as well as their innovative work behaviors (IWBs) have been changed. Based on the positive psychology approach, workplace spirituality and psychological safety are seen as important factors on employees' IWBs. Therefore, this study aimed to examine the relationships among perceived workplace spirituality, psychological safety, and employees' IWBs within the context of the COVID-19 pandemic. Employees working in different private sectors in Istanbul $(\mathrm{N}=251)$ participated in the current research. The statistical analyses revealed that workplace spirituality contributed to employees' innovative behaviors, and psychological safety fully mediated this relationship. Based on the findings, practical and conceptual implications of this study are discussed and future directions are presented.

Key Words: Innovative work behaviors, workplace spirituality, psychological safety perception.

\section{COVID-19 Salgını Döneminde Yenilikçi İç Davranışlarına Yeniden Bakış: Algılanan İşyeri Maneviyatının ve Psikolojik Güvenliğin Etkileri}

\section{ÖZ}

\begin{abstract}
Alanyazında yer alan çalışmalarda, pozitifliğin örgütlerdeki olumlu yansımalarına işaret edilmiş, ancak pozitif psikolojinin bir uzantısı olarak maneviyatın ve güvenlik hissinin yenilikçi iş davranışları (Yid) üzerindeki etkisi hakkında yeterli sayıda bulguya ulaşılmamıştır. Buradan hareketle, bu araştırmada, işyeri maneviyatı, psikolojik güvenlik ve çalışanların yenilikçi iş davranışları arasındaki ilişkinin incelenmesi amaçlanmıştır. Ayrıca, COVID-19 salgının gündeme geldiği örgütsel koşullarda, Yid'i oluşturan koşulların ve süreç esnasında çalışanların işyerine ilişkin tutum ve algılarının da farklılık gösterebileceği öngörülmüştür. $\mathrm{Bu}$ nedenle, çalışmada ele alınan değişkenlerin günümüz çevresel koşullarında çalışanların algı, tutum ve davranışları açısından incelenmesinin alanyazına önemli katkılar sunabileceği düşünülmüştür. Bu bağlamda gerçekleştirilen araştırmaya, İstanbul'da farklı özel sektörlerde çalışan bireyler ( $\mathrm{N}=251)$ katılmıştır. İstatistiksel analizler neticesinde, işyeri maneviyatının çalışanların yenilikçi davranışlarına katkıda bulunduğu sonucuna varılmıştır. Psikolojik güvenliğin, işyeri maneviyatı ve yenilikçi iş davranışları arasındaki pozitif yöndeki bu ilişkide tam aracılık rolüne sahip olduğu bulgusuna ulaşılmıştır. Analizler sonucunda elde edilen bulguların uygulamaya ve alanyazına yönelik katkıları değerlendirilmiştir.
\end{abstract}

Anahtar Kelimeler: Yenilikçi iş davranışları, işyeri maneviyatı, psikolojik güvenlik algısı.

\section{Introduction}

Within the last decades, organizations have faced the challenges of globalization, competition, changing structures, and the diversified workforce that lead them to act innovatively and differently. Together with a variety of challenging and fluctuating socioeconomic environmental factors, at the beginning of 2020, the whole world has encountered an unexpected situation. The outbreak of coronavirus disease (COVID-19) has been demanding for the world and organizations have to behave differently compared to the past. COVID-19 pandemic has created serious harms to the economics, 
organizations, and society. Particularly, psychological problems of individuals, such as panic disorder, anxiety, and depression can be triggered due to the outbreak. Also, there have been discussions about public health systems and economies, after the expansion (McKibbin and Fernando, 2020; Qiu, Shen, Zhao, Wang, Xie, and Xu, 2020). It has been suggested that innovations with several new management practices can meet the rapidly changing demands of the environment (Fernando, Jabbour, and Wah, 2019). For example, employees have been allowed to work in the home office and they have to find new methods to be able to work from home. Healthcare workers are expected to behave innovatively to find quick life-saving solutions in intense and challenging working conditions of the pandemic outbreak. In this context, employees' innovative work behavior (IWB) and its prerequisites have gained more importance. Psychology and organizational behavior studies are valuable to understand innovative behaviors since the significance of individuals' morale, health, and motivation was found to be related to positive organizational outcomes. In this respect, retaining creative individuals might be strategically advantageous for organizations (Riggio, 2012; Robbins and Judge, 2012). In addition to retaining qualified employees, forming a work atmosphere that leads employees to behave innovatively might be critical. Likewise, scholars provided the relationship between IWB and employee level variables (King and Anderson, 2002). It has also been argued that fostering IWB among employees depends on effective human resource management (HRM) practices (Newman, Donohue, and Eva, 2017). In this regard, IWB can be followed by successful implementations of HRM, new management perspectives, and employees' positive effects (Seligman and Csikzentmihalyi, 2014). More specifically, positive psychology and positive organizational behavior approach (Luthans, $2002 b$ ) is in the scope of the current study to understand the psychological background of IWB.

As such, evaluating employees as human beings with their physical, mental, emotional, and spiritual needs is crucial in today's management perspective. Past studies have confirmed that individuals who have experienced public health emergencies as the COVID-19 outbreak still have stress disorders, even if after the event is over (Low and Wilder-Smith, 2005). Therefore, psychological interventions in such crises are continuously considered by scholars and authorities. With this regard, workplace spirituality refers to the recognition of individuals' inner life that is nourished by meaningful work with a feeling of community, and the social bond can play a preventive mechanism for employees' stress and related negative emotions at least during work. This may lead to employees' innovative behaviors which they would be able to find solutions to work problems that are directly or indirectly caused by such environmental issues. Previous studies also concluded that workplace spirituality increase employee engagement, organizational citizenship behavior (OCB) (Saks, 2011), and creativity (Shinde and Fleck, 2015). In addition to the proposed findings from the past research, Pandey, Gupta and Gupta (2019) addressed the need for more empirical evidence regarding the relationship between workplace spirituality and organizational outcomes. Hence, the present study aims to find the relationship between workplace spirituality and IWB. As workplace spirituality may have important implications, another variable that is studied concerning IWB is employees' psychological safety. For being one of the antecedents of employees' psychological contract and organizational trust, psychological safety is a kind of interpersonal safety perception in the organizational context. Psychological safety perception may influence individuals to engage in typical discretionary behaviors, such as IWB. It is suggested that the higher the individuals perceive psychological safety, the higher the discretionary behaviors. In particular, psychological safety perception is regarded as a mediator variable between the organizational characteristics and employee outcomes (e.g., employee attitudes, motivation, performance) (Edmondson and Lei, 2014). From this point of view, the mediating role of psychological safety on the relationship between workplace spirituality and innovative work behaviors will be examined. A detailed review of the literature will be presented based on the previous assumptions.

\section{Literature Review and Conceptual Framework}

The remainder of the paper is organized by initially reviewing the foundation literature for the study and then providing the conceptual and empirical evidence supporting the relationships among the study variables leading to the proposition of hypotheses. 


\section{Innovative Work Behaviors and Workplace Spirituality}

In today's rapidly changing environment the ability of businesses to adopt the changes and to survive is partly dependent on their capability of innovation. In order to be innovative, employees' IWB is crucial because employees carry out innovations during uncertain times where change, novelty, and challenge are needed (e.g. pandemic business context) (Çetinkaya and Gülbahar, 2019). Within this respect, West and Farr (1990) described IWB as employees' intentional and voluntary introduction and/ or application of new ideas, products, processes, and procedures to the organizations and they initially stated two stages for IWB: "idea generation" and "idea implementation". Further studies indicated four stages for IWB (De Jong and Den Hartog, 2008) as "idea generation" (developing new ideas and offering solutions for the problems), "idea promotion" (includes voice and share ideas to other people), "opportunity exploration" (an awareness of the opportunities in organizations), and "idea implementation" (utilizing new ideas in organizations).

It is generally assumed that employees need to have freedom and autonomy for being innovative. Creating such an environment in organizations would contribute to individuals IWB (De Jong and De Hartog, 2010). Especially, the presence of workplace spirituality can be a part of a positive work atmosphere. Thus, a few research has revealed the relationship between workplace spirituality and IWB recently (Pandey et al., 2019), since the concept of spirituality and its relations with workplace issues have received attention in the literature. Before that, classical management theories (e.g., Taylor's scientific management) have been criticized for being against human nature by focusing on productivity, efficiency, and effectiveness in organizations, and the subsequent studies have stated that employees should be evaluated differently than the assumptions of the classical theory of management. However, the idea of focusing on employees' psychology has been expanded among organizational scholars and practitioners (Tasselli, Kilduff, and Landis, 2018), and mental health discourses (e.g., ensuring the positivity to create a psychologically healthy workplace) have been the mostly stdied areas in organizational psychology. According to this perspective, individuals bring their whole self to the organization, where they work for. This wholeness includes their personal beliefs, values, and strengths. Further, as an extension to those arguments, there have been researches and some implementations that showed employees' wellness and positivity are related to the positive organizational outcomes (Alex Linley, Joseph, Harrington, and Wood, 2006; Taştan, 2016). In particular, positive psychology is a related concept for its focus on positivity and it is defined as "at the individual level it is about positive individual traits: The capacity for love and vocation, courage, interpersonal skill, aesthetic sensibility, perseverance, forgiveness, originality, future mindedness, spirituality, high talent, and wisdom." (Seligman and Csikszentmihalyi, 2000, p. 5). As it can be seen in the definition, spirituality might be a part of the positivity in organizations. Thus, spirituality studies and applications are expected to provide new insights to organizations in a pandemic environment. The practices of workplace spirituality may contribute to employees' positive emotions and can play as a preventive mechanism against stress in environmental crises. For example, some global organizations have started to apply meditation training and some spirituality-related practices (Gupta, Kumar, and Singh, 2014). The concept of 'spirit' comes from the word 'soul'. Spirit is described as the basic feeling of being connected with one's complete self, others, and the entire universe (Howard and Welbourn, 2004). Individuals feel interconnected to other people and have a purpose when they feel spiritual (Mitroff and Denton, 1999, p. 83). Therefore, spiritual knowledge introduces individuals to their inner self, a quest for meaning and purpose in life (Seyyar and Evkaya, 2015). In the current study, workplace spirituality is defined based on Kinjerski and Skrypnek's (2004) conceptualization. Accordingly, "spirit at work is a holistic experience where individuals share a sense of interconnectedness and common purpose, authenticity, alignment between their values and actions, feel good about what they do, are aware of a spiritual presence, a sense that they are contributing a to the common good and enjoy mystical moments" (Kinjerski and Skrypnek, 2004, p. 39). Furthermore, the sub-dimensions of the construct of workplace spirituality are indicated as "engaging work" (meaningful work), "mystical experience", "sense of community", and "spiritual connection".

Particular perceptions and feelings that are related to workplace spirituality may have impacts on IWB, such as meaningful work, sense of community, and alignment with organizational values 
(Milliman, Czaplewski and Ferguson, 2003). These factors are suggested to be positively associated with employees' IWB. For instance, Kumar (2016) showed a positive relationship between the subdimensions of workplace spirituality and IWB. Regarding the sense of community, it has been demonstrated that collaboration among employees is related to new idea generation (Sethia, 1991). Meaningful work may also have a significant influence on idea generation. In this respect, Farr and West (1990) assumed that meaningful and enriched jobs require more thinking and creativity when it is compared with simple tasks. According to Spreitzer (1995), meaningful work can be conceptualized as individuals' active orientation to work and it affects employees' desire to participate in the work processes (Spreitzer, 1995). This active orientation may increase autonomy and motivation related to the tasks and employees may have an intrinsic motivation to engage in IWB. If employees find meaning in their work, this perception affects employees' feeling of worth and they can be more creative as a result (Jung, Chow and Wu, 2003). Additionally, if there is an alignment with organizational beliefs and values, it is likely to result in IWB since it is the extension of the philosophy of "right person for the right job". For instance, individuals can make a difference in the work processes if they are the right employees for the organization. These differences are explained by positive work outcomes for organizations (O'Reilly, Chatman and Caldwell, 1991), like IWB. With that aspect, a match between individuals and the organization created conformity that motivates employees for IWB (King- Kauanui, Thomas and Waters, 2005).

According to Gupta and colleagues (2014), organizations that have spirituality are differed from other organizations, because they are characterized by several positive qualities, such as selftranscendence and a sense of community. Similarly, the positive association between the spiritual characteristics of an organization and team-level innovative behavior was revealed in the literature (Pandey et al., 2019). The theoretical background of the relationship between workplace spirituality and IWB can be explained by the Social Exchange Theory (SET) framework. According to Pierce, Gardner, Cummings, and Dunham (1989), if employees feel worthwhile, important, and meaningful for their organizations, they are likely to engage in discretionary workplace behaviors as reciprocity. More specifically, individuals tend to evaluate their worth in a particular context or a specific relationship (Blau, 1964) and they feel that they get some benefits from their organizations through workplace spirituality, this enhances the positive attitudes and behaviors. Employees may also feel a sense of obligation to the organization (Rego and Cunha, 2008) and as an effect of obligation, employees sense an urge to benefit the organization through displaying IWB. Hence, according to the SET framework, if individuals' values are respected, individuals tend to develop positive work attitudes and behaviors (Afsar and Badir, 2017). Based on the SET (Blau, 1964) and the previous researches, the first hypothesis of the study is proposed as follows.

H1: Perceived workplace spirituality has a positive effect on the employees' innovative work behaviors.

\section{The Mediating Role of Psychological Safety}

Organizational learning, adaptation, and innovation are more critical and complex processes enabling a system to adapt to environmental uncertainty and to develop a competitive advantage. Taken together, organizational survival and sustainability depend on how the organization learns, adapts, and responds to uncontrollable contingents in the environment. With that respect, employees are expected to be more flexible, adaptive, and open to learning and innovation, since the innovativeness and growth capacity of the organizations depend on how much their members are involved in decision-making, creative and innovative thinking, team learning, and collaboration. Fundamentally, employees' involvement in joint decision-making, teamwork, collaborative works, and expression of different ideas stem from their psychological comfort and belief in being safe regarding the consequences of exposing self opinions. As Kahn (1990) described, psychological safety is the feeling of being able to show and employ one's self without fear of negative consequences to self-image, status, or career. Thus, psychological safety perception lies behind an individual's risktaking behavior, engagement to changing work patterns, and expression of self opinions, whereas it reduces uncertainty avoidance and fear of rejection or criticism. The extensive literature provides 
conceptual and empirical links of the concept with employee attitudes and behaviors and organizational outcomes (e.g., Carmeli, Brueller and Dutton, 2009; Edmondson, 2018; Vandekerkhof, Steijvers, Hendriks and Voordeckers, 2018; Kanbur and Ay, 2020). The common argument of the previous works is that psychological safety is a psychological resource and it enhances individuals' coping with uncertain conditions, responding to workplace changes, and joining in problem-solving and collaborative processes.

Turning back to the outbreak of the COVID-19 pandemic, employees' mental health and psychology should be discussed more than before. Individuals' psychological states are realized as an important condition for both their positive affection as well as positive employee attitudes and behaviors in work. Taking into account its role in reducing stress and fear of self-presentation in knowledge sharing and participation in cooperative works, psychological safety perception is considerably needed in such kind of uncertain times. Likewise, the previous literature puts forward that psychological safety has an intervening role on the relationship between the employee antecedents and organizational level outcomes of information sharing, innovation, and performance (e.g., Carmeli, Sheaffer, Binyamin, Reiter-Palmon and Shimoni, 2014; Hirak, Peng, Carmeli, and Schaubroeck, 2012; Kostopoulos and Bozionelos, 2011; Newman et al., 2017; Siemsen, Roth, Balasubramanian and Anand, 2009; Walumbwa and Schaubroeck, 2009). Even though there is a gap in the organizational studies about the role of psychological safety on the relationship between workplace spirituality and IWB, some studies and theoretical frameworks might be used to explain this model. For instance, the sense of community as a dimension of workplace spirituality may affect individuals' freedom of expression through the feeling of psychological safety. In other words, the interpersonal relations and the feeling of community reduce ineffective workplace conflicts, increases trust and psychological safety that leads to creativity (Deci, Connell and Ryan, 1989; Oldham and Cummings, 1996) and innovative behaviors (Carmeli, Gelbard and Gefen, 2010). Moreover, researchers indicated that individuals in high-performing work teams have the feeling of community and psychological safety, and individuals in these teams have a high work engagement (Delizonna, 2017). In line with these arguments, Chen and colleagues (2019) unveiled the role of psychological safety on the relationship between spiritual leadership and proactive workplace behavior. Furthermore, Hackman and Oldham's (1976) theory can explain the role of psychological safety on the relationship between workplace spirituality and IWB. Based on the Job Characteristics Model (Hackman and Oldham, 1976), work characteristics affect employees' organizational behaviors through their psychological states. Thus, work characteristics are evaluated as workplace spirituality, whereas employees' psychological states can be psychological safety perceptions and IWB is one of the work outcomes that is affected by workplace spirituality and psychological safety perception. Accordingly, the following hypotheses of the study are suggested as follows. behaviors.

H2: Perceived psychological safety has a positive effect on the employees' innovative work

H3: Perceived psychological safety has a significant mediating role in the relationship between perceived workplace spirituality and employees' innovative work behaviors.

Based on the rationale above, the conceptual framework, presented in Figure 1, displays the suggested relationships.

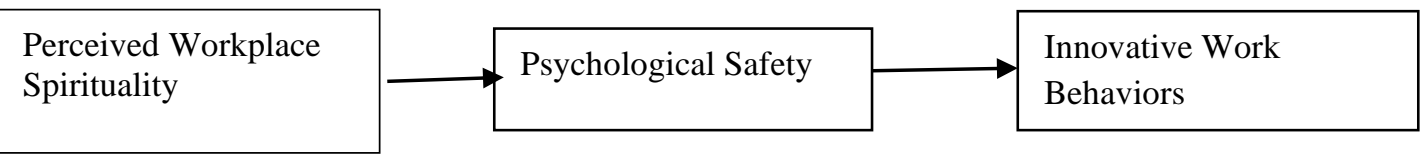

Figure 1.Suggested Conceptual Framework 


\section{Methodology}

In the following part of the study, the research method is described. First, the sampling method and the participants are displayed, then the measures utilized to assess the study variables are explained.

\section{Participants and Procedure}

The convenience sampling method was used in this research. 251 employees who were working in different private sectors in İstanbul, such as technology, Research, and Development (R\&D), Telecommunications, Education, Bank-Finance, and Marketing participated in this research. The questionnaire survey has been performed via an online database between March 2020 and April 2020. The sample was composed of 139 (55.4\%) females and 112 (44.6\%) males with an age of 29.11 (M), while 177 (70.5\%) participants were single and 74 (29.5\%) of them were married. A multi-item questionnaire on a six-point interval scale was used in this research and questionnaires were distributed through online forms. The participants initially completed the demographic questions that included their age, gender, industry, work experience, and educational background. The questionnaire continued with three scales to measure the main variables of this study: workplace spirituality, psychological safety, and innovative work behaviors (IWB). The items were rated on a 6-point interval scale ranging from "totally disagree" (1), to "totally agree" (6).

\section{Measures}

In this part, the measures are described by giving information about their sources and the sample items used in the current research context.

Innovative Work Behaviors (IWBs): IWBs were measured by 14 items that were developed by De Jong and Den Hartog (2010) and Scott and Bruce (1994) to analyze employees' innovative behaviors in more detail. De Jong and Den Hartog's (2010) scale was adapted to the Turkish language by Çimen and Yücel (2017), Scott and Bruce's scale was translated to the Turkish by Çalışkan, Akkoç, and Turunç (2011). De Jong and Den Hartog's (2010) scale measures four dimensions, including "problem recognition", "idea generation", "supporting ideas" and "idea implementation", whereas all the items are collected under one factor in Scott and Bruce (1994)'s IWB scale. The internal consistency of De Jong and Den Hartog's (2010) scale was found to be higher than .70 in their study. The previous studies indicated the reliability of the scale as .86 (Taştan and Davoudi, 2015). In addition, the internal consistency of Scott and Bruce's (1994) scale was found as .89, while other studies revealed the Cronbach alpha of the scale as .87 (Taştan, 2013). An example of items from the scale was: "I pay attention to issues that are not part of your daily work and I wonder how things can be improved."

Workplace Spirituality: The Workplace Spirituality Scale was developed by Kinjerski and Skrypnek (2006) and consists of 18 items. The scale has four dimensions that are "engaging work", "sense of community", "spiritual connection" and "mystical experience". An item example from the scale was "I experience a real sense of trust and a personal connection with my coworkers." The internal reliability of the scale was found as .93 in the original study. The Turkish translation of the scale was done by Ünal and Turgut (2015) and they found the internal consistency of the scale as .93.

Psychological Safety: Edmondson's (1999) "Psychological Safety Scale" was utilized to assess individuals' psychological safety. The scale has 7 items and the Turkish adaptation of the scale was done by both Üçok and Torun (2016) and Yener (2015). The Cronbach alpha value of the scale was found as .79 in Edmondson's (1999) original study, also it was found as .93 in Üçok and Torun's (2016) study. An example item from the scale was "It is difficult to ask other members of my organization for help." 


\section{Findings}

In this part, the research results are presented. First, the reliability and validity analyses outcomes are explained. Then, the reports of the correlation and regression analyses are displayed and statistical findings are highlighted by acknowledging the interpretations for the hypotheses.

\section{Reliability and Validity Analyses}

Initially, skewness and kurtosis values for each item of the scale were evaluated to check out the normality and Confirmatory Factor Analysis (CFA) was performed for evaluating the construct validity of the scales (e.g. Nunnally and Bernstein, 1994; Şimşek, 2007). Cronbach's alpha was used for reliability assessment and the reliability of all the scales were more than 0.7 , which indicated that all the scales demonstrated good reliability. The following Table 1 shows the factor analysis results of workplace spirituality scale. The below Table 1 presents the fitness indices of the study variables based on the CFA.

Table 1

Fitness Indices of Study Variables Based on CFA

\begin{tabular}{lllll}
\hline \multirow{2}{*}{ Fitness indices } & Innovative & Workplace & Psychological & \multirow{2}{*}{ Principle } \\
& Work Behaviors & Spirituality & Safety & $<3$ \\
\hline Chi-square/df & 2.3774 & 2.4155 & 2.3362 & $<0.05$ \\
$p$-value & 0.00 & 0.00 & 0.00 & $<0.10$ \\
RMSEA & 0.065 & 0.062 & 0.068 & $>0.9$ \\
GFI & 0.93 & 0.92 & 0.92 & $>0.9$ \\
AGFI & 0.90 & 0.91 & 0.92 &
\end{tabular}

Note: IWB $\left(\chi^{2} / d f=2.37, s d=140, R M S E A=0.065, G F I=.93, A G F I=.90\right) ;$ Workplace Spirituality $\left(\chi^{2} / d f=2.41\right.$, $s d=143, R M S E A=0.062, G F I=.92, A G F I=.91) ;$ Psychological Safety $\left(\chi^{2} / d f=2.33, s d=142, R M S E A=0.068\right.$, $G F I=.92, A G F I=.92$ ).

It has been indicated that goodness-of fit indexes are expected to be equal to or greater than 0.90 to confirm the model and RMSEA is expected to be less than or equal or 0.05 to state that there is a good model fit. Lastly, when RMSEA is less than or equal to 0.08 , an adequate fit is found (Schumacker and Lomax, 2004). The 14 items IWB scale was averaged for an overall score. Cronbach's Alpha for this scale was yielded as 0.96 in the research setting. The results of CFA showed that the fit index of the scale was acceptable $(\mathrm{x} 2 / \mathrm{df}=2.37, \mathrm{RMSA}=.065$, GFI $=.93$, AGFI $=$ .90) (Çokluk, Şekercioğlu and Büyüköztürk, 2010). The reliability of the workplace spirituality scale was $\alpha=0.93$. The results of the CFA showed that the fit index of the scale was acceptable $(\mathrm{x} 2 / \mathrm{df}=$ $2.41, \mathrm{RMSA}=.062$, GFI $=.92$, AGFI $=.91$ ). Moreover, the 7 items scale of psychological safety showed Cronbach's Alpha as 0.96 and the CFA results revealed that the fit index of the scale was acceptable $(\mathrm{x} 2 / \mathrm{df}=2.33, \mathrm{RMSA}=.068, \mathrm{GFI}=.92$, AGFI $=.92)$. Thus, as can be seen in Table 1 , the findings of the CFA of the variables demonstrated that all the mentioned criteria were measured with the scales. The results of CFA showed good fitness of the models, indicating that the selected indicators are good representatives for each component of the variables of the study.

\section{Results of Correlation and Regression Analyses}

Before regression analyses, the correlations among the research variables were assessed and the findings showed that workplace spirituality, psychological safety and IWB were statistically significantly and positively correlated with each other $(p<.001)$. Descriptive statistics including means and standard deviations and correlations among the main variables are presented in Table 2.

Table 2

Correlation Findings of the Research Variables

\begin{tabular}{|c|c|c|c|c|c|c|c|c|}
\hline & $\mathrm{M}$ & SD & 1 & 2 & 3 & 4 & 5 & 6 \\
\hline 1. Gender & & & 1 & $.058 * *$ & -.077 & $.101 * *$ & $.133 * *$ & $.095 * *$ \\
\hline
\end{tabular}




\begin{tabular}{|c|c|c|c|c|c|c|}
\hline 2. Age & 29.11 & 1.03 & $.488 * *$ & $.205^{* *}$ & $.368 * *$ & $.355^{* *}$ \\
\hline 3. Work Experience & 14.25 & 0.96 & & $.239 * *$ & $.277 * *$ & $.289 * *$ \\
\hline 4.Workplace Spirituality & 3.95 & 1.08 & & & $.424 * *$ & $.419 * *$ \\
\hline 5.Psychological Safety & 4.17 & 1.16 & & & & $.278 * *$ \\
\hline 6. IWB & 4.52 & .93 & & & & 1 \\
\hline
\end{tabular}

Note. $* * * p<.001$.

As it is seen in Table 2, workplace spirituality is significantly and positively correlated with psychological safety $(r=.424)$ as well as IWB $(r=.419 ; p=.01)$ in a moderate magnitude. In addition, it is determined that psychological safety is positively related to individuals' IWBs $(r=.278 ; p=.01)$. Furthermore, multiple regression analysis was used to determine the effects of workplace spirituality and psychological safety on IWBs. Workplace spirituality items served as independent variables and the psychological safety measures were the intervening variables in the model. IWB items were used as the dependent variable. The results of regression analysis are reported in below Table 3 .

Table 3

The Contribution of Workplace Spirituality on IWB and Psychological Safety

\begin{tabular}{ccccc}
\hline Variable & $\beta$ & Std. Error & $t$ & $p$ \\
\hline (Constant) & 3,100 & .203 & 15.281 & $.000^{* * *}$ \\
\hline Workplace Spirituality & .360 & .049 & 7.282 & $.000^{* * *}$ \\
\hline$R^{2}=.176 ; F=53.031 ; p<.001$ & & & \\
\hline$* p<0.05 ; * * p<0.01 ; * * * p<.001$ & Dependent Variable:IWB & $.000^{* * *}$ \\
\hline (Constant) & 2,388 & .251 & $.000^{* * *}$ \\
\hline \multicolumn{7}{l}{ Workplace Spirituality } & .452 & .061 & 9.512 \\
\hline$R^{2}=.180 ; F=54.553 ; p<.001$ & & 7.386 & \\
\hline$* p<0.05 ; * * p<0.01 ; * * * p<.001$ Dependent Var.:Psychological Safety \\
\hline
\end{tabular}

Table 3 shows that workplace spirituality significantly contributed to IWB by showing that IWB can be predicted by perceptions of workplace spirituality $(\beta=.360, p<.01)$. Moreover, as Table 3 illustrates, workplace spirituality significantly contributed to psychological safety (mediating variable; $\beta=.452, p<.01$ ). Thus, the regression analysis results in a significant $\mathrm{p}$-value by showing that workplace spirituality contributed to psychological safety. Subsequently, the regression analyses supported $\mathrm{H} 1$ and $\mathrm{H} 2$.

Further, the mediation model of psychological safety was tested with the bootstrap-based Hayes' PROCESS macro (Hayes, 2012)- a well-established statistical resampling technique that estimates the parameters of the model and their standard errors strictly from the sample (Hayes, Montoya and Rockwood, 2017). When compared with the causal steps model of Baron and Kenny (1986), Hayes' method calculates precise and correct confidence intervals of indirect effects. In sum, the inferred two steps have been applied to obtain adequate results regarding the research model. By that, insignificant results from small-size data sets are prevented and it provides healthy results (Arslan and Yener 2015, p. 297).

The findings of PROCESS macro (Hayes, 2012) with bootstrapping of 5000 are illustrated in Table 4. The total effect of workplace spirituality on IWB was 0.279 , and the indirect effect of workplace spirituality on psychological safety is $b=0.121(p<0.01)$. The bootstrapped confidence interval bias had corrected $95 \%$, and it did not show an interval straddling a 0; thus, H3 is confirmed. According to the results, "psychological safety" fully mediated the relationship between "workplace spirituality" and "IWB".

Table 4

The Mediating Role of Psychological Safety

\begin{tabular}{|c|c|c|c|c|c|c|c|c|c|}
\hline \multirow{2}{*}{$\begin{array}{l}\text { The } \\
\text { Mediation } \\
\text { Effect of }\end{array}$} & \multirow{2}{*}{$\begin{array}{l}\text { Total } \\
\text { Effect }\end{array}$} & \multirow{2}{*}{$\begin{array}{l}\text { Direct } \\
\text { Effect }\end{array}$} & \multirow{2}{*}{$\begin{array}{l}\text { Indirect } \\
\text { Effect }\end{array}$} & \multirow{2}{*}{$\begin{array}{l}P \\
\text { Value } \\
\text { of }\end{array}$} & \multirow{2}{*}{$\begin{array}{l}\text { Bootstrap } \\
\text { Significance } \\
\text { Interval of }\end{array}$} & \multicolumn{3}{|c|}{ Sobel Test } & \multirow{2}{*}{$\begin{array}{l}\text { The Type } \\
\text { of } \\
\text { Mediation }\end{array}$} \\
\hline & & & & & & $\overline{S E}$ & $Z$ & $p$ & \\
\hline
\end{tabular}




\begin{tabular}{llllllllll}
\hline $\begin{array}{l}\text { Psychological } \\
\text { Safety }\end{array}$ & & \multicolumn{1}{c}{$\begin{array}{l}\text { Direct } \\
\text { Effect }\end{array}$} & $\begin{array}{l}\text { Indirect } \\
\text { Effect } \\
\text { LLCI/ULCI }\end{array}$ & & Effect \\
\hline WS $\rightarrow$ IWB & .279 & -.1582 & .121 & .1106 & $\begin{array}{l}-.2483 /- \\
.0393\end{array}$ & .0423 & -2.8723 & .0041 & Full \\
& & & & & & & & &
\end{tabular}

WA: Perceived Workplace Spirituality

IWB: Innovative Work Behaviors

On the other side, even though the primary aim of this study was to understand the contributions of workplace spirituality and psychological safety on IWBs, multiple regression analyses were applied with the sub-dimensions of the workplace spirituality for a detailed understanding on how each dimension explains IWBs. Since workplace spirituality was composed of three factors and were named as "feeling of engagement and community", "spiritual connection", and "engagement to work" in the current research, these three factors were examined as the antecedents of individuals' IWB. As such, for assessing the contributions of the independent variables of workplace sipiruality dimensions on IWBs, multiple regression analysis was performed.

The below Table 5 and Table 6 present the model summary results of the multiple regression analysis.

Table 5

Model Summary of Regression Analysis

\begin{tabular}{lllll}
\hline Model & $R$ & $R^{2}$ & Adj. $R^{2}$ & Std. Error of the Est. \\
\hline 1 & .435 & .189 & .179 & .847 \\
\hline$N o t e:$ Predict
\end{tabular}

Note: Predictors: (Constant), Feelings of engagement and community, Engagement to work

Table 5 indicates that the overall $\mathrm{R}^{2}$ was revealed as .189 suggesting that feelings of engagement and community and engagement to work combine to explain approximately $19 \%$ of the variance in perceived IWBs among the sample group.

Table 6

Summary Results of Coefficients of Regression Analysis

\begin{tabular}{llll}
\hline Dependent Variable: Innovative work behaviors & & & \\
\hline Independent Variables & $\beta$ & $t$ Value & $p$ Value \\
\hline Constant & 3.058 & 14.990 & .000 \\
Feelings of engagement and community & .244 & 3.688 & .000 \\
Engagement to work & .121 & 2.206 & .028 \\
Spiritual connection & .012 & .271 & .787 \\
\hline
\end{tabular}

$R=0.435 ; R^{2}=.189 ; F$ Value $=19.172$

In the above Table 6, it is reported that the effects of "feelings of engagement and community" $(\beta=.244, p<.01)$ and the "engagement to work" $(\beta=.121, p<.05)$ on IWB were found as significant and positive. However, "spiritual connection" did not have a significant effect on IWB ( $p=.787)$. Table 5 and Table 6 present the overall model and the findings $(F=19.72, p<.05)$.

\section{Conclusion, Discussion and Recommendations}

COVID-19 pandemic has been spreading around the world, its psychological effect might be hard to predict from now. However, as the first patients were observed in China, scholars from China have been studying the possible impact of the COVID-19 epidemic in their country since then. Notably, researchers (Cao, Fang, Hou, Han, Xu, Dong and Zheng, 2020) have found that the reflection of highly spreading coronavirus in individuals' daily life (e.g., delays in academic activities and social life) were positively related with college students' anxiety symptoms. Additionally, psychological interventions have been discussed among scholars (Duan and Zhu, 2020). For this respect, rethinking 
the contributions of positive psychology (e.g., psychological safety) and the effects of workplace spirituality on organizational life is beneficial for ensuring the morale of employees and the benefits of organizations. More specifically, employees usually carry out innovations with their behaviors against situations where novelty or quick solutions are needed. Based on this, it is important to understand the relationship between workplace spirituality and IWB variables, including perceived psychological safety. The purpose of the present study was to investigate the relationship between workplace spirituality and IWBs with the mediating role of psychological safety. Following the recent empirical evidence about positive organizational behavior and spiritualism (Alex Linley et al., 2006, Donaldson and Ko, 2010; Kumar, 2016), it was hypothesized that there is a relationship between workplace spirituality and IWBs. Along with the first hypothesis, extant literature has been reviewed to unveil the evidence for potential contingent and intervening variables on this relationship. Subsequently, psychological safety has been discussed as mediating variable that refers to interpersonal perception and psycho-social resource in work (Agarwal and Farndale, 2017; İşiaç1k, 2019; Newman et al., 2017).

Even there were relatively scarce empirical studies that examine psychological safety, workplace spirituality, and IWB together, hypotheses were logically formulated and the suggested relationships have been investigated through cross-sectional research in Turkey. Following the methodological approach, the findings of this research supported the assumptions. The statistical findings showed a positive relationship between workplace spirituality and IWB $(\beta=.360, p<.01)$. This result was in line with some previous discussions in the literature. For instance, Turner (1999) argued that if employees bring their spiritual side to their workplace, they do not behave like a machine or in a routine way, rather they can engage in creative thoughts and behaviors. Kumar (2016) also stated a positive relationship between workplace spirituality and IWB. This finding is related to some theories and perspectives on organizational behavior. One of them SET (Blau, 1964), as mentioned previously. In other words, workplace spirituality refers to positivity, such as the feeling of community and meaningful work that may contribute to employees' positive affections. Individuals behave innovatively to help the organization as a return for the benefits they sense workplace spirituality (e.g., positive emotions in the workplace). The positive relationship between workplace spirituality and IWB can also be explained with culture. According to Hofstede (1997, p. 5), culture is "the collective programming of the mind that distinguishes the members of one group or category of people from another". Given the logic that organizational culture is about both formal and informal work context, it guides individuals in their behaviors and can be defined as the shared basic assumptions that characterize the workplace setting. Consequently, workplace spirituality can be linked with organizational cultures. For example, individuals' feeling of community can be a part of organizational culture (see Cameron and Quinn, 2011). In addition, the reflections of workplace spirituality in organizational cultures have been stated in the previous studies. If there is knowledge sharing and solidarity culture in an organization, these characteristics can be related to a spiritual workplace (Alas and Mousa, 2016). Hence, some benefits and characteristics of organizational culture might trigger employees' IWB as well as creativity.

Further, psychological safety was included in the model because of the critical role of psychological safety on IWB (Pandey et al., 2019). The mediating role of psychological safety on the relationship between workplace spirituality and IWB was examined with several statistical analyses. The results indicated the fully mediating role of psychological safety between workplace spirituality and IWB. Workplace spirituality strengthens the psychological safety perception of the employees and they contribute to IWBs. The impact of workplace spirituality on individuals' psychological safety perceptions and IWB was shown in the current research. According to Rego and Cunha (2008), human beings have a spiritual side and it can be crucial to understand the potential outcomes of workplace spirituality on positive work attitudes and/ or behaviors. In other words, for practical implementations, managers should understand the antecedents of workplace spirituality. Within this respect, understanding individuals' values and goals is important, because the congruence between them and organizational values may be critical for creating a spiritual workplace. For example, employee selection and retention are important to ensure IWB in organizations (Riggio, 2012). If employees do not match their significant beliefs and thoughts with their workplace, they may not engage in 
innovative behaviors and may not feel psychologically safe. Likewise, appropriate employee selection is essential for organizations' survival and long-term benefits. After highlighting the importance of employee selection in organizations, HRM and its functions should be emphasized (e.g., Buller and McEvoy, 2012). HR employees play a vital role in all the selection and recruitment processes. Their congruence with the organization and their wisdom and the knowledge about their impact on the whole human process in the organization are significant. For example, as an applicator of workplace spirituality, the HR professional should find meaning in their work. In this case, their educational backgrounds (e.g., being an expert in social sciences), skills, and abilities are important rather than just job experiences in the HR field.

In particular, the influence of psychological safety on individuals' IWB was demonstrated in the current study. In the detailed analyses, psychological safety was predicted by workplace spirituality $(\beta=.452, p=.01)$, while it directly affected IWB $(r=.278 ; p=.01)$. The role of psychological safety on the relationship between workplace spirituality and employees' IWB might be explained through Affective Events Theory (AET; Weiss and Cropanzano, 1996). Psychological safety can be stated as an opposite term of negative emotions in the workplace, such as job stress (Yener, 2015). AET discusses that workplace characteristics influence employees' affections and emotions in organizations. Workplace spirituality may awake individuals' positive emotion-related behaviors and attitudes, such as psychological safety and innovative work behaviors. Delizonna (2017) stated a human evolution perspective of psychological safety and correlated the term with high-performing teams. Accordingly, it can be inferred that such kinds of mental activities encourage individuals' psychological safety, innovative work behaviors, and even performance.

CFA was performed to examine the factorial structure of the scales. According to the findings of CFA, the selected indicators were good representatives for each component of the variables of the study. The results are consistent with previous analyses (İşiaçik, 2019) and the concept of workplace spirituality has three dimensions were confirmed. These dimensions are revealed as "feeling of engagement and community", "spiritual connection", and "engagement to work". Moreover, upon the findings, it can be concluded that the definition of workplace spirituality combines employees' feeling of engagement and community with feeling spiritual at work. In other words, if employees feel blissful and find meaning through the feeling of community, they are probably in a state that is called workplace spirituality. In line with Scott and Bruce's (1994) arguments, the IWB measure has been found as a unidimensional construct in the present study. The IWB measurements can still open to more confirmatory analyses because of the inconsistent discussions and evidence.

In addition, the effects of feelings of engagement and community, engagement to work, and spiritual connection were examined for a detailed understanding. Interestingly, the spiritual connection did not predict IWB $(p>.05)$, while both feelings of engagement and community and engagement to work positively contributed IWBs. It seems that individuals' engagement and positive interpersonal relationships at work more effective on discretionary behaviors. Consistent with the previous studies (Fox, Webster, and Casper, 2018; Mónico, Mellão, Nobre-Lima, Parreira, and Carvalho, 2016), workplace spirituality contributed to individuals' psychological safety in the present study. It is concluded that spirituality serves as a psychological resource for the individuals at the workplace and enhances IWB. In sum, positive employee behaviors and performance outcomes are associated with satisfying individuals' psychological needs and this suggestion is more denotative especially within challenging environmental situations. Besides the practical implications, there are contributing conceptual implications of the current research. Firstly, the impact of individuals' psychological factors and spirituality levels in their workplaces on employees' behavioral outcomes has been underlined in the current study. As stated before, innovation is crucial to today's rapidly changing environment. With this logic, psychological safety perception and the proceeds of workplace spirituality can be highly important to understand the success stories of organizations and may give inspirations to possible new management techniques.

The current research has some limitations because of the absence of the moderating variables. The reason for this can be the possible significant factors that strengthen and weaken the relationships 
between the variables. As Taştan, Gücel and İşçi (2017) suggested employees' assumptions about the world, as well as their autonomy perceptions, influence their positive workplace behaviors. From this point of view, it may also be beneficial to study the impacts of workplace spirituality on different positive workplace attitudes and behaviors, such as psychological safety and IWB on the side of individuals' self-construals. Further, even though this study did not focus on a certain sector, studying a particular industry may be beneficial to understand workplace behaviors in more detail. As Gupta (2017) recommended a sector-specific study for workplace spirituality, the model of this research should be investigated in the critical sectors that are important in today's business world. While we stated the impact of workplace spirituality on positive workplace attitudes and behaviors (psychological safety and IWB), different empirical studies are necessary to reveal the possible workplace spirituality implications and employee outcomes. Another limitation of this study can be self-report surveys. The data collection method may be extended for later studies. As Üçler and Taştan's (2018) study, individuals' in-role and extra-role performance behaviors were measured and rated by their supervisors and they suggested that multiple data collection methods may be useful to gain more valid data. Thus, individuals' IWB can be rated by their supervisor and/or might be obtained from the performance evaluation results of the organizations in later researches. Such a method can lead to eliminating potential social desirability bias. Additionally, larger sample size is recommended for future studies to get more generalizable findings. Since this study was conducted in a limited sample group through a cross-sectional survey, a longitudinal study may be beneficial to understand the possible interactions and changes among the variables. Finally, even though there were two main hypotheses in the current paper to explore the relationships among the focal variables, future studies can be executed through the relevant hypotheses.

\section{Author Contribution Statement}

The first author contributed $60 \%$ and the second author $40 \%$ to this article.

\section{Conflicts of Interest}

There is no conflict of interest in this study.

\section{References}

Agarwal, P. and Farndale, E. (2017). High-performance work systems and creativity implementation: The role of psychological capital and psychological safety. Human Resource Management Journal, 27(3), 440-458.

Afsar, B. and Badir, Y. (2017). Workplace spirituality perceived organizational support and innovative work behavior: The mediating effects of person-organization fit. Journal of Workplace Learning, 29(2), 95-109.

Alas, R. and Mousa, M. (2016). Organizational culture and workplace spirituality. International Journal of Emerging Research in Management and Technology, 5(3), 285-314.

Arslan, A. ve Yener, S. (2015). Temel benlik değerlendirmeleri-girişimci kişilik ilişkisinde ençoklamacı karar verme yaklaşımının aracı değişken rolü: Konya örneği. İşletme Araştırmaları Dergisi, 7(3), 283-310.

Alex Linley, P., Joseph, S., Harrington, S. and Wood, A. M. (2006). Positive psychology: Past, present, and (possible) future. The Journal of Positive Psychology, 4(1), 3-16.

Baron, R. M. and Kenny, D. A. (1986). The moderator-mediator variable distinction in social psychological research: Conceptual, strategic, and statistical considerations. Journal of Personality and Social Psychology, 51(6), 1173. 
Blau, P. (1964). Power and exchange in social life. NY: John Wiley \& Sons.

Buller, P. F. and McEvoy, G. M. (2012). Strategy, human resource management and performance: Sharpening line of sight. Human Resource Management Review, 22(1), 43-56.

Cameron, K. S. and Quinn, R. E. (2011). Diagnosing and changing organizational culture: Based on the competing values framework. John Wiley \& Sons.

Cao, W., Fang, Z., Hou, G., Han, M., Xu, X., Dong, J. and Zheng, J. (2020). The psychological impact of the COVID-19 epidemic on college students in China. Psychiatry Research, 28(1), 1-6.

Carmeli, A., Brueller, D. and Dutton, J. E. (2009). Learning behaviours in the workplace: The role of high-quality interpersonal relationships and psychological safety. Systems Research and Behavioral Science: The Official Journal of the International Federation for Systems Research, 26(1), 81-98.

Carmeli, A., Gelbard, R. and Gefen, D. (2010). The importance of innovation leadership in cultivating strategic fit and enhancing firm performance. The Leadership Quarterly, 21, 339-349.

Carmeli, A., Sheaffer, Z., Binyamin, G., Reiter-Palmon, R. and Shimoni, T. (2014). Transformational leadership and creative problem-solving: The mediating role of psychological safety and reflexivity. The Journal of Creative Behavior, 48(2), 115-135.

Chen, S., Jiang, W., Zhang, G. and Chu, F. (2019). Spiritual Leadership on Proactive Workplace Behavior: Identification and Psychological Safety. Frontiers in Psychology, 10, 1206.

Çalışkan, A., Akkoç, İ. and Turunç, Ö. (2011). Örgütsel Performansın arttırılmasında motivasyonel davranışların rolü: Yenilikçiliğin ve girişimciliğin aracılık rolü. Süleyman Demirel Üniversitesi İktisadi ve İdari Bilimler Fakültesi Dergisi, 16(3), 363-401.

Çetinkaya, F. F. and Gülbahar, H. O. (2019). Stratejik yönetim ve inovasyon ilişkisi: KOBİ'ler üzerine bir araştırma. Ahi Evran Üniversitesi Sosyal Bilimler Enstitüsü Dergisi, 5(2), 349-367.

Çimen, İ. and Yücel, C. (2017). Yenilikçi Davranış Ölçeği (YDÖ): Türk kültürüne uyarlama çalışması. Cumhuriyet Uluslararası Eğitim Dergisi, 6(3), 365-381.

Çokluk, Ö., Şekercioğlu, G. ve Büyüköztürk, Ş. (2012). Sosyal bilimler için çok değişkenli istatistik: SPSS ve LISREL uygulamaları (Vol. 2). Ankara: Pegem Akademi.

Deci, E. L., Connell, J. P. and Ryan, R. M. (1989). Self-determination in a work organization. Journal of Applied Psychology, 74(4), 580.

De Jong, J. P. and Den Hartog, D. N. (2008). Innovative work behavior: Measurement and validation. EIM Business and Policy Research, 8(1), 1-27.

Delizonna, L. (2017). High-performing teams need psychological safety: Here is how to create it. Harvard Business Review, 8, 2017.

Duan, L. and Zhu, G. (2020). Psychological interventions for people affected by the COVID-19 epidemic. The Lancet Psychiatry, 7(4), 300-302.

Edmondson, A. (1999). Psychological safety and learning behavior in work teams. Administrative Science Quarterly, 44(2), 350-383. 
Edmondson, A. C. and Lei, Z. (2014). Psychological safety: The history, renaissance, and future of an interpersonal construct. Annu. Rev. Organ. Psychol. Organ. Behaviour, 1(1), 23-43.

Edmondson, A. C. (2018). The fearless organization: Creating psychological safety in the workplace for learning, innovation, and growth. John Wiley \& Sons.

Farr, J. L. and West, M. A. (Eds.). (1990). Innovation and creativity at work: Psychological and organizational strategies. Wiley.

Fernando, Y., Jabbour, C. J. C. and Wah, W. X. (2019). Pursuing green growth in technology firms through the connections between environmental innovation and sustainable business performance: Does service capability matter?.Resources,Conservation and Recycling,141,820 .

Fox, C., Webster, B. D. and Casper, W. C. (2018). Spirituality, psychological capital and employee performance: An empirical examination. Journal of Managerial Issues, 30(2), 194-153.

Gupta, M., Kumar, V. and Singh, M. (2014). Creating satisfied employees through workplace spirituality: A study of the private insurance sector in Punjab (India). Journal of Business Ethics, 122(1), 79-88

Gupta, A. A. K. (2017). Workplace Spirituality-A New Paradigm in Management. Ushus-Journal of Business Management, 16(2), 45-52.

Hackman J.R. and Oldham, G.R. (1976). Motivation through the design of work: Test of a theory. Organizational Behavior and Human Performance, 16, 250-279.

Hayes, A. F. (2012). PROCESS: A versatile computational tool for observed variable mediation, moderation, and conditional process modeling [White paper]. Retrieved fromhttp://www.afhayes.com/public/process2012.pdf.

Hirak, R., Peng, A. C., Carmeli, A. and Schaubroeck, J. M. (2012). Linking leader inclusiveness to work unit performance: The importance of psychological safety and learning from failures. The Leadership Quarterly, 23(1), 107-117.

Hofstede, G. (1997). Cultures and organizations: Software of the mind. New York: McGrawHill.

Howard, S. and Welbourn, D. (2004). The spirit at work phenomenon. Landon: Azure.

İşiaçik, S. (2019). The impact of perceived corporate social responsibility and workplace spirituality on innovative work behaviors: The role of psychological safety perception. (Unpublished master's thesis). Marmara University Institute of Social Sciences, İstanbul.

Jung, D. I., Chow, C. and Wu, A. (2003). The role of transformational leadership in enhancing organizational innovation: Hypotheses and some preliminary findings. The Leadership Quarterly, 14(4-5), 525-544.

Kanbur, E. and Ay, A. (2020). Psikolojik sözleşme algısının işe adanmışlık üzerindeki etkisi. Ahi Evran Üniversitesi Sosyal Bilimler Enstitüsü Dergisi, 6(2), 531-549.

King, N. and Anderson, N. (2002). Managing innovation and change: A critical guide for organizations. Cengage Learning EMEA. 
King-Kauanui, S., Thomas, K. D. and Waters, G. R. (2005). Entrepreneurship and spirituality: integration of spirituality into the workplace. Journal of Management, Spirituality \& Religion, 2(2), 255-274.

Kinjerski, V. M. and Skrypnek, B. J. (2004). Defining spirit at work: Finding common ground. Journal of Organizational Change Management, 17(1), 26-42.

Kinjerski, V. and Skrypnek, B. J. (2006). Measuring the Intangible: Development of the Spirit at Work Scale. Academy of Management Proceedings, 1, 1-6.

Kostopoulos, K. C. and Bozionelos, N. (2011). Team exploratory and exploitative learning: Psychological safety, task conflict, and team performance. Group \& Organization Management, 36(3), 385-415.

Kumar, M. (2016). Workplace Spirituality and Employee Work Attitudes: Exploring Gender as a Moderator. Journal of Business and Management, 18(5), 1-10.

Low, J. G. and Wilder-Smith, A. (2005). Infectious respiratory illnesses and their impact on healthcare workers: a review. Ann Acad Med Singapore, 34(1), 105-110.

Luthans, F. (2002b). The need for and meaning of positive organizational behavior. Journal of Organizational Behavior, 23, 695-706.

McKibbin, W. J. and Fernando, R. (2020). The global macroeconomic impacts of COVID-19: Seven Scenarios. CAMA Working Paper No. 19/2020.

Milliman, J., Czaplewski, A. J. and Ferguson, J. (2003). Workplace spirituality and employee work attitudes: An exploratory empirical assessment. Journal of Organizational Change Management, 16(4), 426-447.

Mitroff, I. I. and Denton, E. A. (1999). A study of spirituality in the workplace. MIT Sloan Management Review, 40(4), 83-103.

Mónico, L. S., Mellão, N., Nobre-Lima, L., Parreira, P. and Carvalho, C. (2016). Emotional intelligence and psychological capital: What is the role of workplace spirituality. Review of Portugual Port. Enferm. Saúde Mental, 3, 45-50.

Nembhard, I. M. and Edmondson, A. C. (2006). Making it safe: The effects of leader inclusiveness and professional status on psychological safety and improvement efforts in health care teams. Journal of Organizational Behavior, 27(7), 941-966.

Newman, A., Donohue, R. and Eva, N. (2017). Psychological safety: A systematic review of the literature. Human Resource Management Review, 27(3), 521-535.

Nunnally, J. C. and Bernstein, I. H. (1994). Validity. Psychometric Theory, 3, 99-132.

Oldham, G. R. and Cummings, A. (1996). Employee creativity: Personal and contextual factors at work. Academy of Management Journal, 39(3), 607-634.

O'Reilly, C.A., Chatman, J. and Caldwell, D. F. (1991). People and organizational culture. Academy of Management Journal, 34(3),487-516.

Pandey, A., Gupta, V. and Gupta, R. K. (2019). Spirituality and Innovative Behavior in Teams: Examining the Mediating Role of Team Learning. IIMB Management Review, 4(2), 1-23. 
Pierce, J. L., Gardner, D. G., Cummings, L. L. and Dunham, R. B. (1989). Organization-based selfesteem: Construct definition, measurement, and validation. Academy of Management Journal, 32(3), 622-648.

Qiu, J., Shen, B., Zhao, M., Wang, Z., Xie, B. and Xu, Y. (2020). A nationwide survey of psychological distress among Chinese people in the COVID-19 epidemic: implications and policy recommendations. General Psychiatry, 33(2), 1-24.

Rego, A. and Cunha, M. P. (2008). Workplace spirituality and organizational commitment: an empirical study. Journal of Organizational Change Management, 21(1), 53-75.

Riggio, R. E. (2012). Industrial and Organizational Psychology. New York: Pearson Higher Edcation.

Robbins, S. P. and Judge, T. (2012). Organizational Behavior. Upper Saddle River, New Jersey: Pearson/Prentice Hall.

Saks, A. M. (2011). Workplace spirituality and employee engagement. Journal of Management, Spirituality \& Religion, 8(4), 317-340.

Schumacker, R. E. and Lomax, R. G. (2004). A beginner's guide to structural equation modeling. Psychology press, New York: Routletge, Taylor \& Francis.

Scott, S. G. and Bruce, R. A. (1994). Determinants of innovative behavior: A path model of individual innovation in the workplace. Academy of Management Journal, 37(3), 580-607.

Seligman, M. E. and Csikszentmihalyi, M. (2000). Positive psychology: An introduction. American Psychologist, 55, 5-14

Sethia, N. (1991). The evocation of creativity through collaboration. In annual meeting of the Academy of Management, Miami.

Seyyar, A. and Evkaya, C. (2015). Batıda "İşyeri Maneviyatı" Üzerine Yapılan Bilimsel Çalışmaların Türk Bilim Camiasına Etkileri. Siyaset, Ekonomi ve Yönetim Araştırmaları Dergisi, 2(2), 1-20.

Shinde, U. and Fleck, E. (2015). What spirituality can bring to leaders and managers:Enabling creativity, empathy and a stress free workplace. Journal of Organizational Psychology, 15(1), 101-120.

Siemsen, E., Roth, A. V., Balasubramanian, S. and Anand, G. (2009). The influence of psychological safety and confidence in knowledge on employee knowledge sharing. Manufacturing \& Service Operations Management, 11(3), 429-447.

Spreitzer, G. M. (1995). Psychological empowerment in the workplace: Dimensions, measurement, and validation. Academy of Management Journal, 38(5), 1442-1465.

Şimşek, Ö. F. (2007). Yapısal eşitlik modellemesine giriş:(temel ilkeler ve LISREL uygulamaları). İstanbul: Ekinoks Publishing.

Tasselli, S., Kilduff, M. and Landis, B. (2018). Personality change: implications for organizational behavior. Academy of Management Annals, 12(2), 467-493.

Taştan, S. B. (2013). The influences of participative organizational climate and self-leadership on innovative behavior and the roles of job involvement and proactive personality: A survey in the context of SMEs in Izmir. Procedia-Social and Behavioral Sciences, 75, 407-419. 
Taştan, S. B. and Davoudi, S. M. M. (2015). An examination of the relationship between leadermember exchange and innovative work behavior with the moderating role of trust in leader: A study in the Turkish context. Procedia-Social and Behavioral Sciences, 181, 23-32.

Taştan, S. B., Güçel, C. and İşçi, E. (2015). Dünyaya ilişkin varsayımlar ve özerklik algısının çalışanlarda olumlu sosyal davranışlar ve saldırganlık ile ilişkilerinin incelenmesi: Özbelirleme ve pozitif yanılsamalar kuramları bağlamında bir değerlendirme. İs'te Davranış Dergisi, 2(2), 1-10.

Taştan, S. B. (2016). Predicting job strain with psychological hardiness, organizational support, job control and work overload: an evaluation of Karasek's DCS model. Postmodern Openings, 7(1), 107-130.

Turner, J. (1999). Spirituality in the workplace. CA Magazine, 132(10), 41-52.

Unnikrishnan, N. K. (2001). Adaptation to creation: Progress of organizational learning and increasing complexity of learning systems. Systems Research and Behavioral Science, 18(6), 505-521.

Üçler, Ç. and Taştan, S. B. (2017). Investigating the relations of psychological contract, organizational transparency and leader-member exchange with employee performance behaviors. Journal of Behavior at Work, 2(2), 89-107.

Üçok, D. T. and Torun, A. A. (2016). The relationship of group cohesiveness, psychological safety, control over work, and competitive work environment with organizational silence: The mediating role of motives of silence. Uluslararası İsletme, Ekonomi ve Yönetim Perspektifleri Dergisi, 4, 62-80.

Ünal, Z. M. ve Turgut, T. (2015). Örgüt kültürünün iş yerinde maneviyat üzerindeki katkısl. 3. Örgütsel Davranış Kongresi Bildiriler Kitabı, Tokat.

Walumbwa, F. O. and Schaubroeck, J. (2009). Leader personality traits and employee voice behavior: mediating roles of ethical leadership and work group psychological safety. Journal of Applied Psychology, 94(5), 1275.

West, M.A. and Farr, J. L. (1989). Innovation at Work: Psychological Perspectives. Social Behavior, 4,15,30.

Weiss, H.M. and Cropanzano. R. (1996). Affective Events Theory: A theoretical discussion of the structure, causes and consequences of affective experiences at work. Research in Organizational Behavior, 18, 1-74.

Vandekerkhof, P., Steijvers, T., Hendriks, W. and Voordeckers, W. (2018). Socio-emotional wealth separation and decision-making quality in family firm TMTs: The moderating role of psychological safety. Journal of Management Studies, 55(4), 648-676.

Yener, S. (2015). Psikolojik Rahatlık Ölçeğinin Türkçe Formunun Geçerlik ve Güvenilirlik Çalışması. ODÜ Sosyal Bilimler Araştırmaları Dergisi, 5(13), 280-305. 


\section{Genişletilimiş Özet}

Tüm dünyayı etkisi altında bırakan COVID-19 salgını ve beraberinde getirdiği psikolojik ve ekonomik zorluklar örgütler açısından dikkate alınması gereken önemli çevresel faktörler içerisinde yer almaktadır. $\mathrm{Bu}$ salgın ortamında, örgütlerin rekabet güçlerini koruyabilmek ve varlıklarını sürdürebilmek için yenilikçi olmaları gerekmektedir. Söz konusu yenilikçi yaklaşımlar, örgütün sunduğu ürün ve hizmeler ile olabildiği gibi çalışanlarına yönelik örgüt içi uygulamaları da kapsamaktadır. Bu noktada birçok örgüt, gerek ürün ve hizmetlerinin üretiliş ve sunuluş biçimlerine olmak üzere gerekse de çalışanlarını salgından korumak adına daha önce uygulamadıkları çeşitli yönetim tarzlarını hayata geçirmişlerdir. Örneğin pandemi sürecinde daha önce uzaktan çalışmaya geçmemiş birçok kurum daha esnek bir çalışma tarzına geçiş yapmıştır. İlaveten, çalışanların da bu değişimlere ayak uydurarak gerektiğinde yenilikçi davranışlara başvurabilmeleri beklenebilmektedir. $\mathrm{Bu}$ bağlamda, yenilikçi iş davranışları (YID) COVID-19 salgını etkisindeki iş dünyası için tekrar incelenmesi gereken bir kavramdır. Örgütsel Davranış alanında YİD'in öncelleri açısında birçok kanıt ortaya konulmuştur. YİD'e katkı sağlayan öncellerin en başında insan psikolojisine olumlu etkisi olduğu ifade edilen yönetim uygulamaları, örgüt atmosferi ve çalışan tutumları olduğu ifade edilmiştir. $\mathrm{Bu}$ nedenle, çalışanları fiziksel, zihinsel, duygusal ve ruhsal ihtiyaçları ile birlikte değerlendirmek günümüz yönetim perspektifinde oldukça önemlidir. Geçmişte yapılan çalışmalar da COVID-19 salgını gibi kamu sağlığını açısından çok riskli olaylara maruz kalan bireylerin, olay bittikten sonra bile hala stres bozukluklarına sahip olduklarını doğrulamıştır (Low ve Wilder-Smith, 2005). Bu bağlamda, bireylerin iç dünyalarının beslendiği, yüksek bir topluluk ve sosyal bağ duygusu ile işinde anlam bulma olarak tanımlanan işyeri maneviyatı, çalışanların stresinin yanı sıra iş esnasında yaşanan kötü duygular için önleyici bir mekanizma olarak rol oynayabilmektedir. İşyerinde algılanan maneviyat, çalışanların bu tür çevresel sorunlardan doğrudan veya dolaylı olarak kaynaklanan problemlerine çözüm bulabilecekleri yenilikçi davranışlara yol açabilmektedir. Önceki araştırmalarda, işyeri maneviyatının, çalışan katılımını, örgütsel vatandaşlık davranışını (OCB) (Saks, 2011) ve yaratıcılığ 1 (Shinde ve Fleck, 2015) artırabileceği sonucuna varabileceği ifade edilmiştir. Bu bulgulara ek olarak, Pandey, Gupta ve Gupta (2019) işyeri maneviyatı ile örgütsel sonuçlar arasındaki ilişkiye dair daha fazla görgül kanıtlara ihtiyaç olduğunu ifade etmiştir. Bu nedenle, bu çalışma, işyeri maneviyatı ile YID arasındaki ilişkiyi değerlendirmeye dair yeni bir bulgu ortaya koymayı amaçlamaktadır.

Öte yandan, işyeri maneviyatının insan psikolojisi üzerinde önemli etkileri olabileceği için, YİD ile ilgili olarak incelenen bir diğer değişken de çalışanların "psikolojik güvenliği”" olmuştur. Önceki çalışmalarda da öne sürüldüğü gibi, psikolojik güvenlik, bireylerin YİD gibi isteğe bağl1 gönüllü davranışlarda bulunmalarını etkileyebilecek önemli bir kavramdır. Psikolojik güvenlik, çalışanların psikolojik sözleşmelerinin ve örgütsel güveninin öncüllerinden biri olması bakımından, örgütsel bağlamdaki bir tür kişiler arası güvenlik algısı olarak karşımıza çıkmaktadır. Konu ile ilgili kuramsal ve görgül çalışmalarda, bireylerin psikolojik güvenliği ne kadar çok algıladıklarına bağlı olarak örgüte katkı sağlayan davranışlarının da o kadar yüksek olabileceği ileri sürülmüştür. Buna göre, psikolojik güvenlik, Yİ'in yordayıcılarından biri olarak araştırılabilmektedir (Nembhard ve Edmondson, 2006). Özellikle, psikolojik güvenlik algısının, örgütsel özellikler ve çalışanların sonuçları (örneğin, çalışanların tutumları, motivasyonu ve performansları) arasında bir arabulucu değişken olarak görülebileceğinin vurgulanmıştır (Edmondson ve Lei, 2014). Söz konusu kuramsal ve görgül çalışmaların aktarımlarına dayanarak, bu çalışmada psikolojik güvenliğin işyeri maneviyatı ile YIDD arasındaki ilişkideki aracı rolünün incelenmesi amaçlanmıştır. Psikolojik güvenlik algısının işyeri maneviyatının YİD ile olan bağlantısındaki rolünün ne olabileceğine dair yeterli bulgular bulunmadığından dolayı, bu çalışmanın kuramsal ve görgül katkılarının olabileceği düşünülmektedir.

\section{Yöntem}

Araştırmanın verileri özel sektörde çalışmakta olan 251 kişiden toplanmıştır. Araştırmada, De Jong ve Den Hartog (2010)' un geliştirdiği Çimen and Yücel (2017)'in Türkçe'ye adapte ettiği 10 maddelik ölçek ile Scott ve Bruce (1994) tarafından geliştirilen 4 madde kullanılarak katılımcıların yenilikçi davranışları ölçülmüş̧ür. Ayrıca, Kinjerski and Skrypnek (2006)'in Ünal ve Turgut (2015) 
tarafından Türkçe'ye uyarlanan 'İşyeri Maneviyatı Ölçeği' ile Edmondson (1999) tarafindan geliştirilip Üçok ve Torun (2016) ve Yener (2015) tarafindan Türkçe'ye adaptasyonu yapılan 7 maddelik "Psikolojik Güvenlik Ölçeği” kullanılmıştır.

\section{Sonuç, Tartışma ve Öneriler}

$\mathrm{Bu}$ çalışmada elde edilen sonuçlar 1şığında, kriz durumlarında (COVID-19 salgını gibi), maneviyat, insanlık ve ilgili olumlu tutumlara çok daha fazla ihtiyaç duyulduğu söylenebilmektedir. Önceki araştırmalarla (Fox, Webster ve Casper, 2018; Mónico, Mellão, Nobre-Lima, Parreira ve Carvalho, 2016) tutarlı olarak, bu çalışmada da işyerinde maneviyat algısının bireylerin psikolojik güvenliğine katkıda bulunduğu gözlenmiştir. Dolayısıyla, işyerindeki maneviyatın çalışanlar için bir tür psikolojik kaynak olarak hizmet ettiği ve algılanan psikolojik güvenliğin katkısıyla yenilikçi davranışların geliştirildiği sonucuna varılmıştır. Bu çalışmadan çıkarılacak başka bir sonuç ise bireylerin kontrol edilemeyen dış koşullarla başa çıkabilmeleri için işyeri maneviyatının potansiyel bir rolü olduğudur. Özetle, pozitif çalışan davranışları ve performans davranışları, bireylerin manevi ihtiyaçlarının örgütler tarafından karşılanması ile ilişkilendirilebilir ve bu ilişki özellikle zorlu çevre koşullarında daha anlamlıdır. Gelecekteki araştırmalarda ise, benzer ilişkilerdeki olası şartlı değişkenlerin rolünün araştırılmasının yararlı olacağı ön görülmektedir. Taştan, Gücel ve İşçi (2017)' nin ifade ettiği gibi çalışanların dünya hakkındaki varsayımlarının yanı sıra özerklik algıları pozitif işyeri davranışlarını etkileyebilmektedir. $\mathrm{Bu}$ bakış açısından incelendiğinde, işyeri maneviyatının, bireylerin benlik düşünceleri açısından psikolojik güvenlik ve YİD gibi farklı pozitif işyeri tutum ve davranışları üzerindeki etkilerini incelemek de yararlı olabilecektir. Bu çalışma için kısıt olarak da çalışanların kendilerini değerlendirdiği ölçeklerin kullanılmış olması ifade edilebilmektedir. Tek kaynaklı veri toplama yönteminden ziyade çoklu kaynak yönteminden yararlanmak daha güvenilir sonulara ulaşılması bakımından yararlı olacaktır. Daha sonraki çalışmalar için veri toplama yönteminin ve örneklem grubunun genişletilmesi önerilmektedir. Böylece, daha genellenebilir sonuçların elde edilmesi mümkün olabilecektir. 